\title{
Література
}

1. Винославська О. В. Психологічні особливості студентської групи / О. В. Винославська // Практична психологія та соціальна робота. - 2005. - № 7. - С. 65-87. 2. Зимняя И. А. Педагогическая психология / И. А. Зимняя - Ростов-на-Дону : Феникс, 1997. - 480 с. З. Лутошкин А. Н. Как вести за собой: Старшеклассникам об основах орг. Работы / под ред. Б. 3. Вульфова. 3-е изд., перераб, и доп. - М. : Просвещение, 1986. - 208 с.: ил. 4. Тлумачний словник української мови / за ред. Д. Г. Гринчишина. - 3-е вид., перероб. і допов. - К. : Освіта, 1999 - 302 с.

\section{ПЕДАГОГІЧНІ УМОВИ ПІДГОТОВКИ МАЙБУТНІХ ВИХОВАТЕЛІВ ДОШКІЛЬНИХ НАВЧАЛЬНИХ ЗАКЛАДІВ ДО РОБОТИ 3 ДІТЬМИ 3 ФУНКЦІОНАЛЬНИМИ ПОРУШЕННЯМИ ОПОРНО-РУХОВОГО АПАРАТУ}

Шовкопляс О. М. Педагогічні умови підготовки майбутніх вихователів дошкільних навчальних закладів до роботи з дітьми з функціональними порушення опорно-рухового апарату.

У статті розглядається структура необхідних педагогічних умов, для ефективного процесу формування готовності майбутніх вихователів до роботи 3 дошкільниками, що мають функціональні порушення опорно-рухового апарату.

Ключові слова: педагогічні умови; майбутні вихователі, дошкільники.

Шовкопляс О.Н. Педагогические условия подготовки будущих воспитателей дошкольных образовательных учреждений к работе с детьми с функциональными нарушениями опорнодвигательного аппарата.

В статье рассматривается структура необходимых педагогических условий для эффективного процесса формирования готовности будущих воспитателей к работе с дошкольниками, которые имеют функциональные нарушения опорно-двигательного аппарата.

Ключевые слова: педагогические условия; будущие воспитатели, дошкольники.

Shovkoplyas O.M. Pedagogical conditions of future teachers of preschool education to work with children with functional disorders of the musculoskeletal system.

This paper deals with determination of the necessary educational conditions for the efficient process of formation of future teachers to work with preschool children with functional disorders opine motor system.

Key words: teaching conditions, future educators, preschool children.

У Національній доктрині розвитку освіти України у XXI столітті турботу про здоров'я підростаючого покоління визначено пріоритетним завданням. Головну увагу акцентовано на тому, що заклади освіти повинні створювати відповідні умови для збереження й укріплення здоров'я кожної дитини. Однак, останнім часом, за даними НДІ гігієни і профілактики захворювань дітей, підлітків та молоді, у нашій державі виявлено несприятливу тенденцію до погіршення стану здоров'я дошкільників: знизилося число абсолютно здорових дітей і збільшилося число дітей, що мають різні відхилення у стані здоров'я, хронічні захворювання. За даними академіка Л. Бадаляна, більше 50 \% дошкільників 3-6 років мають функціональні відхилення, 3 них: 30-40 \% опорно-рухового апарату, 20-25 \% дихальної системи, у 30-40\% дітей молодшого і 20-30\% старшого дошкільного віку фіксуються неврологічні вияви.

Особливе занепокоєння викликає той факт, що у дітей 3-6 років хвороби кістковом'язової системи (порушення постави, пласкостопість, сколіоз тощо) займають 1-е місце за поширеністю: порушення постави виявлено майже у 80 \%, а пласкостопість - у $40 \%$ дошкільників. Функціональні відхилення визначаються у 40-50 \% цих дітей, початкові 
ознаки патології різних ланок опорно-рухового апарату у $74 \%$, функціональна неповноцінність кардіо-респіраторної системи у $36 \%$.

Порушень у стані здоров'я дітей значною мірою можна запобігти за умов своєчасної профілактики й корекції відхилень засобами фізичного виховання. Сучасні дошкільні заклади потребують вихователів із високим рівнем науково-педагогічної та практичної готовності до організації занять з дітьми, що мають відхилення у стані здоров'я. Це вимагає від дошкільних працівників наявності загальних і спеціальних знань й практичних умінь 3 окресленої проблеми, а також систематичного роботи 3 їх удосконалення.

Педагогічною практикою доведено, що процес навчання підпорядкований впливу багатьох чинників, які у свою чергу визначаються внутрішніми й зовнішніми умовами. Закономірності таких впливів повинні братися до уваги під час відбору умов, які забезпечують процес підготовки майбутніх вихователів.

Цілісна ієрархічна системи таких умов ще не знайшла грунтовного розроблення, тому під час їх відбору необхідно враховувати конкретні характеристики предмету дослідження.

Значимість тієї чи тієї умови визначається успішністю здійснюваного процесу та виражається досягненням такого рівня професійної готовності, який відповідає реальним можливостям майбутніх вихователів.

Метою статmі є виокремлення основних педагогічних умов, які можуть сприяти ефективному формуванню готовності майбутніх вихователів до роботи 3 дітьми 3 функціональними порушеннями ОРА.

На основі аналізу психолого-педагогічної літератури ми дійшли глибокого переконання, що готовність вихователя до роботи 3 дітьми 3 функціональними порушеннями опорно-рухового апарату (OPA) $є$ об'єктивним процесом і водночас складником професійної підготовки.

Ефективність підготовки майбутніх вихователів до роботи з дітьми з функціональними порушеннями ОРА залежить від низки педагогічних й організаційно-методичних умов.

У філософському енциклопедичному словнику поняття «умова» трактується так: 1) середовище, в якому перебувають та без якого не можуть існувати; 2) ситуація, в якій щонебудь відбувається [3, с. 198]. Об'єднує визначення даного поняття те, що умова - це категорія відносин предмета 3 довкіллям, без якого він не може існувати.

Згідно з визначенням, яке пропонується в іншому філософському енциклопедичному словнику «умова - це те, від чого залежить дещо інше (зумовлене), суттєвий компонент комплексу об'єктів, із наявності якого у разі необхідності відбувається здійснення даного явища» [4].

Така інтерпретація умов пов'язана 3 причинно-наслідковими відношеннями об'єкту дослідження.

У сучасній психолого-педагогічній літературі категорія «умова» розглядається першоосновою родових понять «середовище», «обставини», «ситуація» (Р. Низамов, М. Ушакова, Ж. Шаніна). 3 позиції Н. Посталюк, таке тлумачення педагогічної конструкції є виправданим, оскільки розширює сукупність об'єктів, необхідних для іiі виникнення, існування чи зміни [2].

Дослідники тлумачать педагогічні умови в кількох аспектах: 1) сукупність заходів навчально-виховного процесу, що забезпечують досягнення студентом професійнотворчого рівня діяльності; 2) сукупність заходів навчально-виховного процесу, що забезпечують досягнення студентом більш високого рівня педагогічній діяльності; 3) змінні, що забезпечують 3 необхідною і достатньою повнотою відбір специфічного змісту, форм, методів навчання і виховання студентів для розв'язання конкретного педагогічного завдання (В. Андреєв, Г. Вергелес, Т. Клімова). При цьому під заходами навчально-виховного процесу, на думку В. Андреєва, слід розуміти зміст, методи (прийоми) та організаційні форми навчання, а також мотиваційну зумовленість навчально- 
пізнавальної діяльності, пов'язану з розвитком особистих мотивів навчання до суспільно значущих.

Автори вкладають в термін «умова» різноманітні компоненти. Так, Н. Кузьмина вважає, що умови «визначаються цілями, які постають перед системою та відповідними змістом, засобами діяльності, кваліфікацією педагогів і підготовки учнів» [1, с. 42]. Ю. Якуба зауважує, що для успішного здійснення зв'язку теорії 3 практикою в навчальному процесі необхідні певні дидактичні умови, які охоплюють як змістовий, так i процесуальний аспекти навчально-виховної роботи. Він підкреслює, що система умов повинна забезпечувати творче використання засвоєних студентами знань та застосування ними свого практичного, трудового досвіду під час вивчення навчальних предметів [5, c. 18].

Спираючись на результати аналізу професійної літератури та на власний досвід, під педагогічними умовами ми розуміємо взаємопов'язану сукупність заходів у навчальновиховному процесі, що повинна забезпечити досягнення студентами високого рівня готовності до роботи з дітьми з функціональними порушеннями ОРА.

Пошуку педагогічних умов, здатних значно підвищити ефективність навчальновиховного процесу у вищій школі, присвячено дослідження В. Пустовойтова, Н. Шведова, Н. Яковенко, Ю. Якуби та ін. Узагальнений аналіз досліджень зазначених науковців дозволяє констатувати, що вони виокремлюють достатньо традиційні умови: оптимальне поєднання колективних й індивідуальних форм навчальної діяльності; використання наочних форм представлення результатів навчальної роботи; використання засобів обчислювальної техніки там, де можливості традиційних педагогічних засобів не відповідають вимогам інтенсивності та якості навчальної роботи тощо.

Така одноманітність педагогічних умов пояснюється, 3 одного боку, переважно загально-дидактичними підходами до організації навчального процесу у ВН3, з іншого відмінності у визначенні умов, зумовлені метою й завданнями конкретних досліджень, мінливими вимогами суспільства.

Під час виоркремлення педагогічних умов, що забезпечують ефективність формування готовності майбутніх вихователів до роботи 3 дітьми 3 функціональними порушеннями OPA, ми дотримувались позиції, що успіх виокремлення умов залежить від чітко визначеної кінцевої мети або результату якого потрібно досягнути; урахування факту, що на конкретних етапах педагогічного процесу умови можуть бути результатом, досягнутим у процесі їх реалізації; розуміння того, що будь-який педагогічний процес може успішно функціонувати за певного комплексу необхідних і достатніх умов.

Оскільки для ефективного педагогічного процесу потрібне не лише виокремлення певних педагогічних умов, а створення такого їх комплексу, який був би необхідним i достатнім для успішного формування готовності у майбутніх вихователів до роботи 3 дітьми з функціональними порушеннями ОРА. Отже, буде доречним розглянути поняття «комплекс». Комплекс у перекладі 3 латинського (komplexus - зв'язок, сполучення) означає зв'язок, сполучення, поєднання окремих частин в ціле [3, с. 815]. Зазначене поняття в педагогіці трактується як якісне поєднання окремих компонентів, або процесів у певну сукупність, що відрізняється від звичайної суми своїх частин. Цілісність виявляється в характері зв'язків, які встановлюються між компонентами структури комплексу.

Аналіз наукової літератури свідчить, що нині в педагогіці обгрунтовано різні позиції щодо проблеми визначення необхідних і достатніх умов. На нашу думку, найчіткіше формулювання зазначеної проблеми відображено у філософському витлумаченні. Якщо 3 усіх наборів достатніх умов відібрати загальні, отримаємо необхідні умови, тобто ті, що притаманні кожному процесу чи явищу. Під необхідними педагогічними умовами ми розуміємо ті, що зумовлюють процес формування готовності майбутнього вихователя до роботи 3 дітьми 3 функціональними порушеннями ОРА, а під достатніми - таке їх поєднання, що забезпечує досягненню ефективності процесу, що відбувається. 
Узагальнюючи зазначене вище, комплексом педагогічних умов ефективного формування готовності майбутніх вихователів до роботи 3 дітьми 3 функціональними порушеннями ОРА $\epsilon$ необхідна й достатня сукупність взаємопов'язаних заходів навчально-виховного процесу, дотримання яких забезпечує досягнення студентами високого рівня готовності до даного виду професійної діяльності.

Отже, основними педагогічними умовами формування готовності майбутніх вихователів до роботи 3 дітьми з функціональними порушеннями ОРА ми визначили: рівень мотиваційної і професійно-педагогічної спрямованості до діяльності вихователя; формування теоретико-методичних знань щодо розуміння сутності та механізмів роботи 3 дітьми з функціональними порушеннями ОРА. Внесення до варіативної частини робочих навчальних планів підготовки бакалаврів спецкурсу «Профілактика та корекція функціональних порушень опорно-рухового апарату у дітей дошкільного віку»; оптимальне поєднання змісту, форм та методів навчання задля забезпечення цілісності системи фахової підготовки; застосування спеціального обладнання у процесі опанування методиками діагностики та корекції функціональних порушень ОРА у дошкільників; внесення до змісту педагогічної практики завдань, що формують у студентів уміння здійснювати профілактично-корегувальну роботу 3 дітьми, які мають функціональні порушення ОРА.

Запропоновані педагогічні умови перебувають у тісному взаємозв'язку. Їх дотримання в навчальній практиці вишу сприятиме формуванню готовності майбутніх вихователів до роботи 3 дітьми, які мають функціональні порушення ОРА, зміст яких визначається цілями, задачами, характером майбутньої фахової діяльності та становлять єдність теоретичної, практичної та мотиваційної готовності випускника навчального закладу здійснювати професійну діяльність. Подальшого дослідження потребує детальна характеристика виокремлених педагогічних умов.

\section{Література}

1. Кузьмина Н. В. Профессионализм деятельности преподавателя и мастера производственного обучения профтехучилища / Н. М. Кузьмина. - М. : Высшая школа, 1989. 179 с. 2. Посталюк Н. Ю. Концептуальные основы организации мониторинга региональных систем начального профессионального образования / Н. Ю. Посталюк, С. Ю. Алашеев // Стандарты и мониторинг в образовании. - 2006. - С. 37-43. 3. Философский энциклопедический словарь / Е.Ф. Губский, Г. В. Кораблева, В. А. Лутченко - М. : ИНФРА-М, 2006. - 576 с. 4. Філософський енциклопедичний словник / за ред. В. І. Шинкарука. - К. : Абрикос, 2002. - 392 с. 5. Якуба Ю. А. Связь теоретического и производственного обучения в средних профтехучилищах / Ю. А. Якуба. - М. : Высшая школа, 1986. - 56 с.

УДК [378: 338.48](470+571)

Г. П. Щука, докторант,

Інститут торгівлі, обслуговуючих технологій та туризму, ДВНЗ «Луганський національний університет імені Тараса Шевченка»

\section{ЗМІСТ ПІДГОТОВКИ ФАХІВЦІВ СФЕРИ ТУРИЗМУ У ВИЩИХ НАВЧАЛЬНИХ ЗАКЛАДАХ УКРАЇНИ ТА РОСІЙСЬКОЇ ФЕДЕРАЦЇ: ПОРІВНЯЛЬНИЙ АНАЛІЗ}

Щука Г. П. Зміст підготовки фахівців сфери туризму у вищих навчальних закладах України та Російської Федерації: порівняльний аналіз.

У статті на основі зіставлення, порівняння, узагальнення вітчизняних та російських стандартів підготовки бакалаврів та магістрів туризму визначається спільне та особливе у змісті підготовки фахівців сфери туризму цього рівня, розглядаються можливості запровадження окремих елементів досвіду російських колег у діяльність вітчизняних навчальних закладів, які реалізують напрям підготовки «Туризм».

Ключові слова: галузеві стандарти, підготовка кадрів, професійна туристська освіта, туризм. 